EUROPEAN HONORS COUNCIL

Note

\title{
Relating secondary school to higher education honours programmes
}

Ton van der Valk ${ }^{1}$, Cécile Kleijer ${ }^{1 *}$, Berenice Michels ${ }^{1}$

1. Freudenthal Institute, Utrecht University, the Netherlands; a.e.vandervalk@uu.nl; C.C.Kleijer@uu.nl; B.I.Michels@uu.nl

*Corresponding author: $\underline{\text { C.C.Kleijer@uu.nl }}$

Received: 17 January 2017; Accepted: 20 April 2017; Published: 27 April 2017

Keywords: secondary education, enrichment, science and mathematics

\section{Introduction}

Many talented and motivated secondary school students feel a need for more in-depth and challenging learning activities than the regular curriculum can offer them (Renzulli, 2005).

The U-Talent Academy in the Netherlands is a programme that aims to meet these needs for 11th and 12th grade vwo (pre-university level) students interested in science and mathematics. U-Talent Academy is part of the U-Talent programme, a collaboration between Utrecht University (UU) and Utrecht University of Applied Sciences (HU) in the Netherlands (see www.u-talent.nl, in Dutch). The aim of U-Talent is to strengthen science and mathematics (STEM) education in secondary school and in the bachelor phase of higher education by the valorization of scientific research and the building of a strong, sustainable secondary-higher education network. Important goals are talent development for all students, professional development of secondary and tertiary science and mathematics teachers, and the improvement of study success and transition. Schools can opt for three different levels of participation: ambition, connection or open. In the 2016/17 course, 26 schools from the Utrecht region participated at the ambition level, with about 2000 students taking part in a one-day or longer student activity. At the connection level, 14 schools participated with 900 students taking part in a one- or two-days student activity. The number of schools participating at the open level is variable. In this contribution, the focus is on the intensive U-Talent 'honours' programme.

\section{U-Talent Academy}

The U-Talent Academy (former name: Junior College Utrecht, Van der Valk, 2014) is the UTalent STEM programme for talented and motivated 16-18 year-old students from the ambition schools. It forms a community of like-minded students, promotes academic competences in students, informs them about recent developments in science research and orients them towards future studies. It also has aims for the schools: to stimulate the ambitions of students, to improve the quality of teaching and to keep their teachers connected with the developments in their subjects. 
Started with 21 students in 2004, the U-Talent Academy now welcomes 150 grade 11 and 150 grade 12 students a year from the ambition schools (Van der Valk, Tromp \& Kleijer, 2015). The students are carefully selected. First, grade 10 students are informed about the programme and they can participate in an orienting two-day university course. Then, they can apply for one of the limited number of U-Talent Academy places the school is granted. The schools select and enlist the applicants to the U-Talent Board, which decides about admission.

The programme is partly carried out at the schools, partly at the Utrecht University campus. The U-Talent school programmes are determined by the schools, but agree in including differentiation in science lessons, additional enrichment projects and school community activities. Moreover, students get assignments, preparing for the lessons at the university. In the campus programme, students come to the university campus for two days a month. The programme includes enrichment modules, an excursion e.g. to CERN in Geneva, Switzerland, community activities and writing a ' $U$-Talent thesis'. The enrichment modules are about recent developments in science research. They are developed and taught by secondary school teachers in cooperation with university researchers. Some module titles are 'Ice and climate', 'Membranes', 'Microtubuli' and 'Simulation and games'. Students do their 120 hours 'thesis research' in a research group of Utrecht University and present the results to their teachers, fellow students and parents.

At the end of secondary school, U-Talent students get a U-Talent certificate that gives entrance to the honours programmes of the Faculty of Science of Utrecht University.

\section{Results of the programme}

Students appear to highly appreciate the U-Talent Academy campus programme: a yearly mean score of 7.5 to 8 on a 10-point scale (from very bad to very good). The school programme is appreciated less high (mean 6.7), but the appreciation is very much schooldependent.

Since its start, all but one U-Talent Academy students passed the national examinations with good to excellent grades. More than $80 \%$ of the alumni chose a STEM study in natural sciences or life sciences (including medicine). 30-40 \% opted for studying at Utrecht University (Van der Valk and Pilot, 2012).

Tromp et al. (2014) analysed the study success of U-Talent Academy students studying at Utrecht University and matched them with non-U-Talent Academy students. The U-Talent students accomplished better in the number of EC's accomplished, in marks and in the duration of their study.

\section{Concluding remarks}

The U-Talent Academy is successfully implemented since 2004. The results show that honours education already can start in secondary school, satisfying its students by offering them an additional learning challenge.

For the selected U-Talent Academy students, the gap between secondary and higher education is narrowed or even closed, especially with respect to honours. That is not the case for other students, even if they are very talented. The broader U-Talent programme sees it as its mission to work on a continuous learning trajectory from primary to tertiary education in science and mathematics for all students, the very talented ones as well as the regular ones. 


\section{References}

Renzulli, J.S. (2005). The three ring conception of giftedness. In: R.J. Sternberg and J.W. Davidson, Conceptions of giftedness, pp. 246-279. Cambridge University Press.

Tromp, S., Oomen, C., Bakker, A., \& Eijkelhof, H. (2014). Studiesucces in het WO van deelnemers aan pre-universitaire verrijkingsprogramma's: alumni van het Junior College Utrecht. [Study success in tertiary education of participants to university enrichment programmes]. Paper to the 2014 ORD conference.

Van der Valk, T. \& Pilot, A. (2012). Empowerment and heterogeneity among talented preuniversity science students in an enriched learning environment. In Markic, S., Eilks, I., di Fuccia, D., \& Ralle, B. (Eds.): Issues of Heterogeneity and Cultural Diversity in Science Education and Science Education Research, pp.133-142 Aachen: Shaker Publishing.

Van der Valk, T. (2014). Connecting excellence in secondary and higher education: lessons from Junior College Utrecht. In: Wolfensberger, M.V.C., Drayer, L. \& Volker, J.J.M. (Eds.). Pursuit of excellence in a networked society, pp. 253-262. Münster - New York: Waxmann.

Van der Valk, T., Tromp, S. \& Kleijer, C. (2015). Learning Communities in a STEM Education Network: scaling-up a talent development programme. In: Maaß, K., Törner, G., Wernisch, D., Schäfer, E. \& Reitz-Koncebovski, K. (Eds.) Educating The Educators: International Approaches To Scaling-Up Professional Development In Mathematics And Science Education, pp. 304-315. Münster: WTM - Verlag für wissenschaftliche Texte und Medien. Retrieved from: http://educating-the-educators.phfreiburg.de/images/Proceedings/ConferenceProceedings EducatingTheEducators MaassToe rnerEtAl 2015.pdf 